\title{
土壤管理措施及环境因素对土壤微 生物多样性影响研究进展
}

\author{
钟文辉 ${ }^{1,2}$ * 蔡祖聪 \\ 1 (中国科学院南京土壤研究所土壤与农业可持续发展国家重点实验室, 南京 210008) \\ 2 (南京师范大学化学与环境科学学院, 南京 210097)
}

\begin{abstract}
摘要: 本文综述了土壤管理措施及环境因素对土壤微生物多样性影响的研究进展, 并介绍了土壤微生物多样性的 研究方法。土壤微生物多样性包括微生物物种多样性、遗传多样性和生态多样性。传统上,土壤微生物群落的分 析依赖于培养技术,但使用该技术只能培养和分离出一小部分土壤微生物群落。现在国际上普遍使用 Biolog 分 析、磷脂脂肪酸 (PLFA) 分析和核酸分析等多种现代技术研究和表征土壤微生物多样性。土壤微生物多样性受土 壤管理措施和多种环境因素的影响。农药可能使土壤微生物多样性减少或改变其结构和功能;施有机肥有利于维 持土壤微生物的多样性及活性; 但在施用无机肥的影响上目前的报道有矛盾之处。农业土壤减少耕作可能增加微 生物多样性和生物量; 轮作可能比单一栽培耕作更有利于维持土壤微生物的多样性及活性。土壤微生物多样性也 受土壤有机质、植被、季节变化等因素的影响，且通常遭受干旱、过度放牧、营养缺乏等的胁迫作用。
\end{abstract}

关键词: 土壤, 微生物多样性, 化肥,农药,耕作, 轮作

中图分类号：Q938 文献标识码：A 文章编号：1005-0094(2004) 04-0456-10

\section{Effect of soil management practices and environmental factors on soil mi- crobial diversity : a review}

\author{
ZHON G Wen-Hui ${ }^{1,2}{ }^{*}$, CAI ZurCong ${ }^{1}$ \\ 1 State Key Laboratory of Soil and Sustainable A griculture, Institute of Soil Sciences, Chinese A- \\ cademy of Sciences, Nanjing 210008 \\ 2 College of Chemistry and Environmental Science, Nanjing Normal University, Nanjing 210097
}

\begin{abstract}
In this paper, the effect of soil management practices and environmental factors on soil microbial diversity are reviewed and the methods for studying soil microbial diversity are briefly introduced. Soil microbial diversity includes microbial species diversity, genetic diversity and ecological diversity. Culturing techniques using a variety of culture media are used traditionally to analyze soil microbial communities, but only a small fraction of soil microbial community has been cultured and isolated. Recently several modern methods including Biolog analysis, phospholipid fatty acid analysis and nucleic acid-based analysis have been utilized internationally to study and characterize soil microbial diversity. Soil microbial diversity is affected by many factors including management practices. Application of pesticides usually causes declines in soil microbial diversity or changes in its structure and function. Organic manures are commonly reported to maintain soil microbial diversity and activities, but reports on the effects of inorganic fertilizers have been contradictory. Generally speaking, microbial diversity is higher and biomass is larger in agricultural soils cultivated with reduced tillage and crop rotation than in those soils cultivated with conservation tillage and monoculture. Soil microbial diversity may also be influenced by soil organic matter, vegetation, seasonal change, and usually suffer from stresses such as drought, overgrazing, and nutrient deficiencies.
\end{abstract}

Key words : soil, microbial diversity, fertilizer, pesticide, tillage, crop rotation 


\section{1 引言}

生物多样性及其变化是全球变化研究的重要内 容之一。人为活动已经使生物多样性大幅度下降, 因而引起了人们的高度重视。土壤微生物是土壤有 机质和养分转化、循环的动力, 它们参与土壤有机质 分解、腐殖质形成、土壤养分转化和循环等过程。土 壤微生物群落的组成与活性不仅在很大程度上决定 了生物地球化学循环、土壤有机质的周转及土壤肥 力和质量, 也与植物的生产力有关 (Zelles, 1999)。 土壤微生物可以敏感地指示气候和土壤环境条件的 变化, 土壤微生物参数可能是最早用于反映土壤质 量的指标 (Zelles, 1999)。目前在土壤微生物多样 性的研究方面取得了长足的进步, 这些研究有利于 了解土壤微生物多样性和土壤质量因人类对土壤的 利用和管理和环境条件的改变而发生的变化。

土壤微生物多样性包括微生物分类群 (taxon) 的多样性、遗传 (基因) 多样性和包含功能多样性的 生态多样性 (Johnsen et al. ，2001)。土壤微生物多 样性比较复杂, 研究的难度较大。人们对土壤微生 物多样性的深入了解得益于研究方法的改进和完 善, 经历了由传统研究方法向现代研究方法的过渡。 传统上, 土壤微生物群落的分析多依赖于培养技术, 即使用培养基最大限度地培养各种微生物群体,由 此了解土壤中的可培养微生物群落。但由于只有极 小部分土壤微生物是可培养的 (Amann et al., 1995)，因而此方法所获得的土壤微生物多样性的信 息是有限的。现在国际上普遍使用 Biolog 分析、磷 脂脂肪酸 (PLFA) 分析和核酸分析等多种现代技术, 从不同角度来研究微生物多样性 (Johnsen et al. , 2001）,这些方法可用于分析包括可培养微生物和不 可培养微生物在内的整个微生物群落。其中,Biolog 分析被用作表征微生物群落的功能潜力, 即被用于 估计碳源利用模式等功能多样性 (Garland \& Mills, 1991）;PLFA 分析用于表征土壤中数量上占优势的 微生物, PLFA 的相对量可显示所指示微生物的相 对含量, PLFA 的总量可被用作指示土壤微生物的 生物量 (Zelles , 1999; Findlay, 1996)。核酸分析方 法是目前最重要的土壤微生物多样性研究方法, 该 方法中最常用的是基于 PCR 的核糖体 DNA ( $\mathrm{rD}^{-}$ NA) 分析方法 (即 rDNA 的 DGGE/ TGGE 指纹分析 方法）,即从土壤微生物中扩增小亚基 rRNA 基因
(16S rDNA 或 $18 \mathrm{~S}$ rDNA), 扩增产物用变性梯度凝 胶电泳 (DGGE) 或温度梯度凝胶电泳 ( TGGE) 分离, 由 DGGE 或 TGGE 带谱及进一步对分离的 DNA 片 段的克隆和序列分析, 可了解土壤中微生物的种类 及群落结构。这些现代研究方法的采用使我们能够 获取土壤微生物群落的更全面而完整的信息, 较完 全地了解环境过程和人类活动对土壤微生物多样性 的影响 (Hill et al. 2000)。

土壤微生物多样性受土壤营养状况、pH 值、质 地、温度、水分和通气性等条件的影响, 也因人类对 土壤的利用和管理而发生变化。本文主要综述农药 的应用、施肥、耕作方式和集约管理等土壤管理措施 以及土壤有机质、植被、季节变化和胁迫等与土壤微 生物多样性关系等方面的研究进展。

\section{2 土壤管理措施对土壤微生物多样性的影 响}

\section{1 施用农药}

农药可分为除草剂、杀真菌剂和杀虫剂等。不 同的农药对土壤微生物多样性有不同的影响 ( Edwards , 1989; Topp et al., 1997; Johnsen et al., 2001）, 可能对土壤微生物产生不同程度的抑制作 用, 或者使土壤微生物多样性和生物量减少, 或者使 土壤微生物群落结构和功能发生改变。

有报道认为农药对在土壤氮转化中具有重要作 用的微生物有影响。其中一例是对根瘤菌属 ( $R \mathrm{hi}^{-}$ zobium) 与豆科植物共生固氮的不利影响 (Aggarwal et al. , 1986; Kishinevsky et al., 1988; Revellin et al. , 1992; Ramos \& Ribeiro, 1993), 其他涉及阿维 菌属 (Azospirillum) 和固氮菌属 (Azotobacter) (Banerjee \& Banerjee , 1987; Jena et al.,1987; Martinez Toledo et al. ,1988)。在土壤氮循环中起 重要作用的硝化细菌也会受施用农药的严重影响 (Doneche et al., 1983; Banerjee \& Banerjee, 1987; Martinez Toledo et al. , 1992a ,1992b), 如 Doneche 等 (1983) 发现杀真菌剂代森锰锌 (mancozeb) 对自然 土壤中的好氧性固氮菌和氨氧化细菌有长期 (三个 月) 的抑制作用。

使用 Biolog 方法研究显示, 土壤微生物群落的 功能潜力因除草剂的应用而被改变; 用 DGGE 或 TGGE 分析 16S rDNA 也显示, 经除草剂处理的土 壤中微生物群落结构明显发生变化, 此外微生物的 
活动或生物量也可能因除草剂的应用而降低。如 Engelen 等 (1998) 研究了除草剂 dinoterb 和 metamitron 对细菌群落的影响, 结果表明, 土壤微生 物 Biolog 群落指纹显著地受 dinoterb 的影响, 轻微 地受 metamitron 的影响。16S rDNA 的 TGGE 图谱 也显示 dinoterb 对细菌多样性有显著的影响, 而用 metamitron 处理的 TGGE 图谱类似未处理的对照 样品的图谱。将用 dinoterb 处理的土壤样品的 TGGE 胶中的 DNA 带切下并测序, 发现其中的一 条带与亚硝酸氧化细菌 (Nitrospina 或 Nitrospira) 有关。Fantroussi 等 (1999) 研究了土壤经敌草隆 (diuron)、利谷隆 (linuron) 和绿麦隆 (chlorotoluron) 三种腿除草剂处理 10 年后土壤微生物群落的变化, 结果显示:土壤微生物群落的结构和代谢能力明显 地受长期应用腿除草剂的影响。经腿除草剂处理 后, 土壤细菌多样性减少, 微生物群落结构明显不 同。DGGE 片段的序列分析表明, 经敌草隆和利谷 隆处理的土壤中一组不可培养细菌类受影响最明 显。Wardle 和 Parkinson(1992) 的研究显示, $2,4-二$ 氯苯氧乙酸 $(2,4-D)$ 和草甘瞵 (glyphosate) 两种除草 剂在有杂草存在的试验小区中, 在施用的开始几天 内就减少了微生物的活动或生物量。

在丹麦应用最广泛的杀真菌剂 Fenpropimorph 专一性抑制参与麦角固醇生物合成的两种酶, 虽然 该杀真菌剂是以感染叶 (leaf-associated) 的真菌为靶 目标, 但对土壤真菌也有影响 (Johnsen et al., 2001), 对腐生真菌、原生动物和细菌无急性毒害作

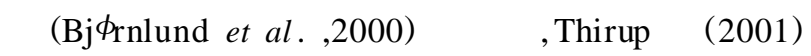
用菌落计数和 rDNA 的 DGGE 指纹分析方法研究 了 Fenpropimorph 对细菌多样性的影响, 结果显示, 在两个月内该杀真菌剂对大麦根中细菌群落的多样 性无影响, 但对腐生真菌有显著影响。在一组平行 试验中发现该杀真菌剂以推荐剂量的 10 倍应用时, 对异养性细菌和其捕食者原生动物之间的相互作用 有影响 (Thirup et al. , 2000)。杀虫剂也可能影响 土壤微生物多样性和活性, 如 Yang 等 (2000) 报道 杀虫剂 triadimefon 在 DNA 水平上影响土壤微生物 群落多样性, 且受 triadimefon 污染的土壤中微生物 生物量碳含量较低。

\section{2 施肥}

土壤微生物的生长受土壤资源的限制。由于微 生物利用高 $\mathrm{C}: \mathrm{N}$ 碳源, 故其生长受氮素限制; 相
反, $\mathrm{C}: \mathrm{N}$ 小于 30 的有机质的分解可导致微生物生 长受碳素的限制 (Aber, 1992; Wardle, 1992; Kaye \& Hart , 1997)。当土壤微生物生长受氮素限制时, 经施肥添加营养可刺激微生物生长 (Aber, 1992; Wardle ,1992; Vanotti et al. ,1995)。Degens(1998) 已证明向土壤中添加简单有机物可改变土壤微生物 的代谢特征和代谢多样性;Bossio 和 Scow (1998) 报 道向土壤中添加碳源能够增加土壤中单不饱和脂肪 酸 (MUFA) 的相对丰度。

研究表明, 施厩肥、绿肥等有机肥有利于维持土 壤微生物的多样性及活性 (Dick, 1992)。如 Bossio 等(1998) 指出在有机低输入系统的土壤中, 高有机 质的输入使微生物生物量持续增加。

在施用无机肥对土壤微生物的多样性及活性的 影响上, 目前的报道有矛盾之处。有的研究表明, 短 期施用无机氮肥对土壤酶活性和微生物生物量只产 生有限的影响, 但长期施用无机氮肥可减少土壤微 生物的活性 (Fauci \& Dick, 1994 ; Lovell et al. , 1995)。Arnebrandt 等(1990)的研究也表明, 施用氮 肥对土壤微生物群落特别是腐生菌和菌根真菌有直 接的抑制作用, 其机制是抑制酶活力和积累毒性化 合物 (Fog, 1988)。Dick (1992) 的研究也显示, 重复 施用无机肥可能抑制土壤中某些酶的产生。Lupwayi 等 (2001b) 认为含硫化肥的应用对土壤微生物 有直接的有害影响或通过作物生长而产生间接的有 益影响, 推测后者是由于含硫化肥能够增强根际中 根的分泌作用。

但是, 另一些研究表明, 长期施用无机氮肥和磷 肥可增加土壤微生物生物量碳和氮 (Kanazawa et al., 1988; Lynch \& Panting, 1982; Goyal et al. , 1992)。Fauci 和 Dick (1994) 在研究无机氮和有机 氮对土壤微生物生物量、代谢熵、参与氮和碳循环的 几种主要土壤酶的长期和短期影响中, 发现在长期 尺度下, 土壤微生物的生物量和酶活性与总氮输入 呈正相关。Yang 等(2000) 的研究显示, 施用碳酸氢 铵可在 DNA 水平上影响土壤微生物群落多样性, 在被碳酸氢铵污染的土壤中微生物生物量碳含量较 高, 表明施碳酸氢铵可导致土壤生物量的增加, 但是 DNA 多样性减少。另外, Sarathchandra等(2001)认 为无机氮肥和磷肥对土壤微生物群落无明显的影 响。

总之, 施用不同种类无机肥对土壤微生物的多 
样性及活性的影响是复杂的, 可能与无机肥的种类、 施用方式 (施用量、长期施用或短期施用) 、土壤类型 和利用方式等因素有关。施用无机肥对土壤微生物 的多样性的影响还有待深入研究。

\section{3 耕作和轮作}

耕作和轮作可能影响农业生态系统的可持续 性。有较多的报道认为, 免耕 (zero tillage) 土壤中微 生物生物量和细菌功能多样性高于传统耕作 (conventional tillage) 土壤, 因为耕作可造成土壤团聚体 的分裂和表层土壤中有机质的损耗 (Carter, 1992; Beare et al.，1994），现已发现大团聚体中的微生物 生物量比微团聚体中的高 (Franzluebbers \& Arshad , 1997)。故减少耕作能增加大团聚体, 可能增 加微生物多样性和微生物生物量 (Lupwayi et al. , $1998,1999,2001 a) 。$

进一步的研究指出, 耕作对土壤微生物多样性 的影响与土壤有机碳含量和土壤酸碱性有关。对近 中性、有机碳含量高的土壤, 耕作大多对微生物无显 著的影响; 但是对酸性和有机碳含量低的土壤, 耕作 可显著降低微生物生物量和多样性 (Lupwayi et al. 2001b)。例如, 耕作可显著 $(P<0.05)$ 降低加 拿大 Alberta 省北部灰色淋溶土中的细菌多样性, 对 微生物多样性的影响在旗叶阶段 (flag-leaf stage) 比 在播种前更为显著; 在旗叶阶段,耕作对非根际土壤 微生物的影响比对根际土壤微生物更为显著 (Lupwayi et al. ,1998)。Yan 等 (2000) 对澳大利亚新南 威尔士州西北两个耕作和两个非耕作变性土（vertisols) 微生物群落功能多样性的研究也显示, 非耕 作土壤的底物丰度、底物利用率和底物利用多样性 高于耕作土壤 (用 Shannon 指数衡量)。分析其原 因 ,据认为传统耕作土壤的 $\mathrm{CO}_{2}$ 排放量 (基础呼吸) 通常高于免耕土壤, 故传统耕作土壤的呼吸商 $\left(\mathrm{qCO}_{2}\right)$ 较高; 而在免耕条件下, 不稳定碳 (labile C) 增加量较高而损失较少, 更多的碳被固定在土壤中, 因此免耕比传统耕作排入大气的 $\mathrm{CO}_{2}$ 少, 土壤有机 质积累较多 (Lupwayi et al.,1999), 有利于增加微 生物多样性。

另外,土壤耕作可能造成土壤结构的恶化,降低 底物丰度和均匀度, 对土壤微生物动力学有负面影 响, 从而显著 $(P<0.05)$ 降低细菌多样性 (Lupwayi et al. , 1998,2001a)。从微生物分布看, 在免耕农业 系统中, 细菌活动随土层深度变化很大, 接近表土中
的细菌活力最强; 而在耕作系统中, 在耕作层内细菌 分布较均匀 (Doran, 1980)。另外, 免耕土壤主要依 赖真菌来分解有机物, 而在传统耕作系统中, 细菌负 责对大部分有机物质的降解 (Kennedy, 1999a)。

轮作可能比采用单一栽培的保护性耕作 (conservation tillage) 更有利于维持土壤微生物的多样性 及活性, 并可抑制在单一栽培系统中易繁衍的有害 微生物及提高农作物产量 (Dick, 1992)。Lupwayi 等 (1998) 在用 Biolog 方法研究轮作对加拿大 $\mathrm{Al}^{-}$ berta 省北部的灰色淋溶土中细菌多样性和群落结 构的影响后指出, 在先前生长红三叶草 (Trifolium pratense) 或豆类的小麦地中, 微生物多样性显著高 于连续种植小麦或夏季休耕的小麦地。此外, 经夏 季休耕的试验地, 通常具有最低的微生物生物量和 $\mathrm{CO}_{2}$ 释放量 (特别是在传统耕作条件下), 而种植豆 科作物后的试验地则具有较高的微生物生物量和较 低的 $\mathrm{CO}_{2}$ 释放量 (Lupwayi et al. , 1999)。这些结 果表明,对该地区的灰色淋溶土实行免耕和用豆科 作物轮作是比传统耕种和休耕更可持续的 (sustainable) 作物管理方法 (Lupwayi et al. , 1998,1999$)$ 。 Alvey 等(2003) 也指出谷物/豆科植物轮作对根际 微生物群落结构有显著影响 $(P<0.05)$, 在连续种 植谷物的土壤中生长的植物有较相似的根际细菌群 落, 而轮作土壤中的微生物群落则出现较大的变异 性。

多数报道认为耕作对土壤微生物多样性或活性 有影响, 但也有少数报道如 Hassink 等 (1991) 认为 传统的和减少输入的农业土壤中微生物群体无明显 差异。

\section{4 集约管理( intensive management)}

研究表明,集约管理不一定影响土壤微生物的 活性, 但可能影响土壤微生物群落结构。对包括牧 草地 (Bardgett et al., 1993; Donnison et al., 2000)、林地、泥炭沼地 (Widden et al. ,1986) 和耕地 (Popova, 1993) 几种生态系统的研究发现, 传统管 理和集约管理的土壤中, 可培养真菌的相对分离频 率不同。此外, 集约管理可降低牧草地或制干草草 原的土壤微生物群落中真菌与细菌的相对比例 (Bardgett et al., 1999; Bardgett \& McAlister, 1999; Donnison et al. ,2000)。举例来说, Donnison 等(2000) 的研究表明,集约管理对制干草草原的土 壤营养状态和土壤微生物的活性无明显影响, 但影 
响土壤微生物群落结构, 造成土壤真菌生物量明显 减少 (通过测定土壤麦角固醇和 PLFA 含量得知) 及 真菌与细菌的相对比例降低。拟青霉 (Paecilomyces sp. ) 、茎点霉 (Phoma sp.) 和几种未鉴定真菌常出 现在传统管理的土壤中, 而黄色镰孢霉 (Fusarium culmorum)、毛霉( Mucor sp.)、Plectos phaerella cucumerina 和 Phoma exigua 则更常出现在集约管理 的土壤中。在一个试验地点, 由于集约管理而导致 的真菌生物量的减少与真菌种组成的变化有关, 但 与腐生真菌的多样性无关, 因而推论虽然改善亚高 山干牧草地的管理可使真菌群落的大小和组成发生 改变, 但不一定影响与有机质分解和营养物循环有 关的土壤微生物群落的功能。

\section{3 其他因素与土壤微生物多样性}

\section{1 土壤有机质}

微生物多样性与土壤类型特别是土壤有机质有 关(Bossio et al. , 1998; Ritchie et al., 2000)。全 球土壤类型多种多样, 构成复杂, 其有机质及矿物质 含量、 $\mathrm{pH}$ 值、机械组成、团聚体组成等理化特征各不 相同。其中土壤有机质的类型和含量对提供维持土 壤各种功能所必需的能量、底物和生物多样性至关 重要 (Franzluebbers, 2002), 土壤有机质的有效性 (availability) 和组成是影响微生物生物量以及群落 组成的关键因素 (Tiquia et al., 2002 ; Boehm et $a l$. , 1997)。研究表明, 土壤微生物活性受有机质 转化和土壤结构的影响 (Garcia et al.,1994)。土壤 有机碳与土壤微生物功能多样性之间存在明显的相 关性 (Yan et al.，2000)。Degens 等 (2000) 通过测 量土壤对多种简单有机化合物的短期呼吸反应来衡 量分解代谢均匀度 (catabolic evenness), 并以该指标 评价土壤微生物多样性 (分解代谢均匀度值高表示 土壤微生物多样性丰富), 发现微生物分解代谢均匀 度与土壤有机碳库 (pool) 绝对值的相关性差 $\left(R^{2}<\right.$ $0.36)$, 但其变化范围与有机碳变化范围有关 $\left(R^{2}=\right.$ $0.76)$,与微生物生物量碳 $\left(R^{2}<0.45\right)$ 或可矿化碳 $\left(R^{2}<0.13\right)$ 的相关性较差。由此推论, 消耗土壤有 机碳储备的土地利用方式可能引起土壤微生物群落 的分解代谢多样性降低。尽管土地利用对微生物过 程的作用仍不清楚, 但是维持土壤有机碳可能对保 持微生物多样性是重要的。

研究还表明,有机农业能增进土壤肥力和土壤
微生物多样性, 有机土壤中微生物多样性的增加又 可改进对土壤的能源和资源物质的利用。此外, 有 机农业生态系统对胁迫和扰动有更强的抵抗力 (Fliessbach et al. ,2000)。

\section{2 植被}

植被通过影响土壤含水量、温度、通气性、 $\mathrm{pH}$ 值 及有机碳和氮的水平而影响土壤生物区系 (Paul \& Clark, 1989)。Waid (1999) 认为植被的类型、数量 和化学组成可能是土壤生物多样性变化的主要推进 力量。他分析指出, 植被是土壤生物赖以生存的有 机营养物和能源的重要来源, 此外活的植被影响土 壤生物定居的物理环境, 包括影响植物凋落物 (litter)的类型和堆积深度、减少水分从土壤表面的损 失率等。他还认为植物对土壤大型生物群 (如蚯蚓、 白蚁和其他节肢动物等) 的结构和功能多样性产生 显著的影响, 且自然植被被作物 (特别是连续单一作 物) 替代时可能改变微生物区系的组成和降低其功 能多样性。Schutter 等 (2001) 指出, 有些土壤中微 生物群落结构和 Biolog 潜能的变化与冬季是否种植 覆盖作物 (欧美国家以减少冬季土壤裸露、抑制硝态 氮淋溶等为目的而种植的作物) 有关, 冬季种植覆盖 作物的土壤比休耕土壤检测出较高含量的真菌和原 生动物脂肪酸甲酯, 此外覆盖作物的残体 (residues) 可增加土壤中脂肪酸甲酯多样性和 Biolog 多样性。 总而言之, 植被的存在有利于增加土壤微生物多样 性和微生物生物量, 植被的破坏可能改变土壤微生 物区系的组成和降低土壤微生物多样性。

\section{3 植物根际}

根际是受植物根系影响的土壤区域。根系 (活 的、逐渐衰老的和死的) 及其分泌物可为微生物提供 生长基质和有利的生长环境。故土壤根际包含可影 响植物生长和健康、多样性丰富的微生物 (Campbell \& Greaves, 1990)。研究表明, 根际和非根际土壤中 的微生物多样性不同, 表现之一是它们的脂肪酸甲 酯谱不同 (Ibekwe \& Kennedy, 1998)。根际中微生 物分类群 (taxa) 的多样性和组成可受植物种 (Miller et al., 1989; Grayston et al. , 1998)、土壤类型 (Hoitink \& Boehm, 1999)、土壤管理措施、微生物 相互作用 (Hedges \& Messens, 1990) 和其他环境因 素 (Kennedy,1999b) 等的影响。其中, 施肥、轮作和 耕作等土壤管理措施可能会有助于一些而不利于另 一些根际微生物生长 (Workneh \& van Bruggen, 
1994)。举例来说, Grayston 等 (1998) 在两种不同类 型土壤中栽种小麦、黑麦草 (Lolium perenne)、剪股 颖 ( A grostis capillaris) 和三叶草 (Trifolium repens), 在种植期间 (4 个星期) 加入蔗糖以模仿碳 输入, 在实验结束时抽提根际微生物群落, 用 Biolog 分析方法评价微生物群落的唯一碳源利用特性。结 果显示, 来自不同植物根际的微生物群落的碳源利 用特性有明显的差别, 据分析差别主要由碳水化合 物、羧酸和氨基酸造成。但来自两种不同类型土壤 的微生物群落之间却无差异。对可培养微生物进行 分离和计数证实了根际对微生物的生长 (特别是对 假单胞菌增殖) 的刺激作用。

\section{4 季节变化}

微生物的生长受温度、水分的影响。在不同的 季节微生物多样性和活性可能不同。土壤微生物活 性通常在夏天比较高而在冬天比较低。Liu 等 （2000）用 Biolog 分析方法证明在美国新墨西哥州 北部 Chihuahuan 沙漠牧场中微生物的功能多样性 在夏天最高, 春天最低; 在夏天干旱试验区比在夏天 和春天的对照中更低, 并认为底物有效性 (availability) 是在一个季节内影响土壤微生物多样性和活性 的最重要的因素。Bossio 等 (1998) 的研究也表明, 在有机和传统的耕作系统中土壤的 PLFA 谱从 4 月 到 7 月间明显不同。Schutter 等(2001) 指出, 早春 土壤中通常真核生物脂肪酸甲酯含量高, 而在夏季 作物收获时的土壤中检测到较高比例的细菌脂肪酸 甲酯。在一个季节内, 群落脂肪酸甲酯和 Biolog 模 式与土壤特性有关。在早春和收获时栽种作物的土 壤中脂肪酸甲酯特征明显与土壤质地 (texture)、阳 离子交换容量和碳含量有关。

\section{5 胁迫 (stress)}

胁迫包括化学胁迫和物理胁迫。在大多数生态 系统中, 物理胁迫比化学胁迫更普遍。比如牧场土 壤的物理胁迫包括干旱、过度放牧、火烧、土壤侵蚀 和土壤压实等。胁迫可降低土壤微生物生物量和多 样性 (Atlas , 1984)。在半干旱和干旱地区, 干旱可 能是影响微生物群落多样性和活性的主要胁迫因 子。干旱胁迫可降低底物的扩散作用和增加微生物 对碳和氮的需求 (Schimel，1995)。目前对受扰动的 干旱牧场的微生物多样性、微生物活性、植物质量和 生态系统的可持续性之间的关系还了解不多 (Liu et al. , 2000) ,但已知在干旱条件下残存的微生物
是少数具有特殊性能的微生物 (Atlas et al., 1991）。过度放牧可能造成牧场生物多样性的损失、 生物区系功能多样性的下降和生态系统作用过程的 恶化 (Fleischner, 1994)。但是 Liu 等 (2000) 却认 为美国新墨西哥州北部 Chihuahuan 沙漠牧场的微 生物多样性和活性均不受过度放牧的影响, 并认为 火烧牧场会减少土壤微生物的多样性和大多数酶的 活力。另一方面, 由于土地利用导致微生物代谢多 样性的降低和土壤特性的改变, 可能减弱微生物群 落对胁迫或扰动 (disturbance) 的抵抗力 (Degens et al.，2000，2001）。响应胁迫而发生的土壤微生物 活性的改变最终能够影响植物的生产力和生态系统 功能 (Liu et al. , 2000)。

\section{4 结论与展望}

土壤微生物与生物地球化学循环、土壤质量与 健康、植物的生产力和农业的可持续发展有关。研 究土壤微生物多样性可了解土壤微生物和土壤质量 因环境条件的改变及人类对土壤的利用而发生的变 化,为农业的可持续发展研究和生态环境的保护提 供依据。

土壤是微生物的大本营,土壤微生物多样性研 究是当今较为热门课题, 目前已经取得了长足的进 展。研究成果的取得得益于研究方法的改进、创新 和完善。由于土壤微生物的复杂性和土壤中绝大多 数微生物不可培养性, 需要采用多种研究方法特别 是现代微生物多样性研究方法, 从不同角度进行研 究, 这样才能获得土壤微生物群落多样性的更全面 而完整的信息,使我们能够较完全地了解环境条件 的变化和人类活动对土壤微生物多样性的影响。传 统上采用的琼脂培养基培养方法由于只能了解土壤 中可培养微生物群落, 因而只能作为研究土壤微生 物多样性的一种辅助方法。

土壤微生物多样性受土壤营养状况、 $\mathrm{pH}$ 值、质 地、温度、水分和通气性等条件的影响, 也因人类对 土壤的利用和管理发生变化。任何能改变土壤性质 或植被的管理措施均可影响土壤生物区系, 其中任 何一个措施均可不同程度地影响土壤含水量、温度、 通气性、 $\mathrm{pH}$ 值及有机碳和氮的水平 (Paul \& Clark, 1989）。土壤微生物多样性和活性在不同的季节可 能不同, 通常在夏天比较高而在冬天比较低。胁迫 可能降低土壤微生物多样性。由于土地利用导致的 
微生物代谢多样性的降低和土壤特性的改变, 可能 减弱微生物群落对胁迫或扰动的抵抗力。

任何对土壤中微生物活性和功能的扰动都可能 影响土壤的长期生产力, 并可能产生严重后果。为 了农业的可持续发展, 在农业活动中应注意保护土 壤微生物多样性。保护植被不仅有利于维护生态平 衡, 而且有利于保护士壤微生物多样性。农药对土 壤微生物多样性有不利影响, 在施用农药时需要考 虑农药带来的不利后果。减少耕作可能增加农业土 壤中的微生物多样性和生物量; 轮作可能比单一栽 培耕作有利于维持土壤微生物的多样性及活性, 是 可持续的土壤管理措施。有机农业不仅能增进土壤 肥力, 还能增加土壤微生物多样性, 有机土壤中微生 物多样性的增加又可改进对土壤的能源和资源物质 的利用, 故施有机肥也是可持续的土壤管理措施。 施用无机肥 (特别是无机氮肥、磷肥和钾肥) 可维持 或增进作物产量, 但在对土壤微生物多样性及活性 的影响上, 目前的报道有矛盾之处, 有待于更深入地 研究在不同土壤类型和利用方式下无机肥及其施用 方式对土壤微生物多样性的影响。

\section{参考文献}

Aber, J. D. 1992. Nitrogen cycling and nitrogen saturation in temperate forest ecosystems. Trends in Ecology and Evolution, $7: 220$ - 223.

Aggarwal, T. C. , Narula, N. and Gupta, K. G. 1986. Effect of some carbamate pesticides on nodulation, plant yield and nitrogen fixation by Pisum sativam and Vigna sinensis in the presence of their respective rhizobia. Plant and Soil, $94: 125$ - 132.

Alvey, S., Yang, C. H. , Buerkert, A. and Crowley, D. E. 2003. Cereal/legume rotation effects on rhizosphere bacterial community structure in west African soils. Biology and Fertility of Soils, $37: 73-82$.

Amann, R. I. , Ludwig, W. and Schleifer, K. H. 1995. Phylogenetic identification and in situ detection of individual microbial cells without cultivation. Microbiological $R^{-}$ view , 59:143 - 169 .

Atlas, R. M. 1984. Use of microbial diversity measurements to assess environmental stress. In: Klug, M. J . and Reddy, C. A. (eds.), Current Perspectives in Microbial Ecology. American Society for Microbiology, Washington, D. C. , 540 - 545 .

Atlas, R. M., Horowitz, A., Krichevsky, M. and Bej, A. K. 1991. Response of microbial populations to environ- mental disturbance. Microbial Ecology, 22 :249 - 256.

Arnebrandt, K. , B "th, E. and S 9 derstr 9 , M. B. 1990. Changes in micro-fungal community structure after fertilisation of Scots pine forest soil with ammonium nitrate or urea. Biology and Fertility of Soils, 22:309 - 312.

Banerjee, A. and Banerjee, A. K. 1987. Influence of captan on some microorganisms microbial processes related to the nitrogen cycle. Plant and Soil, 102:239 - 246.

Bardgett, R. D., Whittaker, J. B. and Frankland, J. C. 1993. The effects of agricultural practises on the soil biota of some upland grasslands. Agriculture, Ecosystems and Environment, 45 : 25 - 45.

Bardgett, R. D. , Lovell, R. D. , Hobbs, P. J.and Jarvis, S. C. 1999. Seasonal changes in soil microbial communities along a fertility gradient of temperate grasslands. Soil Biology and Biochemistry, 31: 1021 - 1030.

Bardgett, R. D. and McAlister, E. 1999. The measurement of soil fungal-to-bacterial biomass ratios as an indicator of $e^{-}$ cosystem self-regulation in temperate meadow grasslands. Biology and Fertility of Soils, 29:282 - 290.

Beare, M. H. , Hendrix, P. F. and Coleman, D. C. 1994. Waterstable aggregates and organic matter fractions in conventional and notill soils. Soil Science Society of A merica Journal, $58: 777$ - 786.

Bjфpnlund, L. , Ekelund, F., Christensen, S. , Jacobsen, C. S. , Krogh, P. H. and Johnsen, K. 2000. Interactions between saprotrophic fungi, bacteria and protozoa on decomposing wheat root in soil influenced by the fungicide Fenpropimorph[Corbel (R) ] : a field study. Soil Biology and Biochemistry, 32 : 967 - 975.

Boehm, M. J., Wu, T. , Stone, A. G. , Kraakman, B. , Iannotti, D. A. , Wilson, G. E. , Madden, L. V. and Hoitink, H. A. J. 1997. Crosspolarized magic-angle spinning ${ }^{13} \mathrm{C}$ nuclear magnetic resonance spectroscopic characterization of soil organic matter relative to culturable bacterial species composition and sustained biological control of Pythium root rot. Applied and Environmental Microbiology, $63: 162$ - 168 .

Bossio, D. A. and Scow, K. M. 1998. Impacts of carbon and flooding on soil microbial communities: phospholipid fatty acid profiles and substrate utilization patterns. Microbial Ecology, 35 :265 - 278.

Bossio , D. A. , Scow, K. M., Gunapala, N. and Graham, K. J. 1998. Determinants of soil microbial communities: effects of agricultural management, season, and soil type on phospholipid fatty acid profiles. Microbial Ecology, 36:1 -12 .

Campbell , R. and Greaves, M. P. 1990. Anatomy and community structure of the rhizosphere. In: Lynch, J. M. 
(ed.), The Rhizosphere. Wiley, Chichester, 11 - 34.

Carter, M. R. 1992. Influence of reduced tillage systems on organic matter, microbial biomass, macroaggregate distribution and structural stability of the surface soil in a humid climate. Soil and Tillage Research, 23:361 - 372 .

Degens, B. P. 1998. Microbia functional diversity can be influenced by the addition of simple organic substrates to soil. Soil Biology and Biochemistry, 30: 1981 - 1988.

Degens, B. P. , Schipper, L. A. , Sparling, G. P. and Vojvodic-Vukovic, M. 2000. Decreases in organic C reserves in soils can reduce the catabolic diversity of soil microbial communities. Soil Biology and Biochemistry, 32 : 189 196.

Degens, B. P. , Schipper , L. A. , Sparling, G. P. and Duncan , L. C. 2001. Is the microbial community in a soil with reduced catabolic diversity less resistant to stress or disturbance? Soil Biology and Biochemistry, 33 : 1143 - 1153.

Dick, R. P. 1992. A review : long-term effects of agricultural systems on soil biochemical and microbial parameters. $A^{-}$ griculture, Ecosystems and Environment, 40: 25 - 36.

Doneche, B., Seguin, G. and Ribereaur Gayon, P. 1983. Mancozeb effect on soil microorganisms and its degradation in soils. Soil Science, 135 : 361 - 366.

Donnison, L. M. , Griffith, G. S. , Hedger, J . , Hobbs, P. J . and Bardgett, R. D. 2000. Management influences on soil microbial communities and their function in botanically diverse haymeadows of northern England and Wales. Soil Biology and Biochemistry, $32: 253$ - 263.

Doran , J. W. 1980. Soil bacterial and biochemical changes associated with reduced tillage. Soil Science Society of A merica Journal, 44 : 765 - 771.

Edwards, C. A. 1989. Impact of herbicides on soil ecosystems. Critical Reviews in Plant Science, 8:221 - 257.

Engelen, B. , Meinken, K. , von Wintzingerode, F. , Heuer, H. , Malkomes, H. P. and Backhaus, H. 1998. Monitor ing impact of a pesticide treatment on bacterial soil commur nities by metabolic and genetic fingerprinting in addition to conventional testing procedures. Applied and Environmental Microbiology, 64 :2814 - 2821.

Fantroussi, S. E. , Verschuere, L. , Verstraete, W. and Top , E. M. 1999. Effect of phenylurea herbicides on soil microbial communities estimated by analysis of 16S rRNA gene fingerprints and community-level physiological profiles. Applied and Environmental Microbiology, $65: 982$ $-988$.

Fauci, M. F. and Dick, R. P. 1994. Soil microbial dynamics: short- and long-term effects of organic and inorganic nitrogen. Soil Science Society of A merica Journal, 58:801 808 .
Findlay, R. 1996. The use of phospholipid fatty acids to determine microbial community structure. In: Akkermans, A. D.L., van Elsas, J. D. and de Bruijn, F. J. (eds.), Molecular Microbial Ecology Manual. Kluwer Academic Publishers, Dordrecht , 1 - 17.

Fleischner, T. L. 1994. Ecological costs of livestock grazing in western North America. Conservation Biology, 8 : 629 644.

Fliessbach, A., Mader, P., Dubois, D. and Gunts, L. 2000. Results from a 21-year-old field trial. Organic farming enhances soil fertility and biodiversity. FiBL Dossier, No. 1 , 15.

Fog, K. 1988. The effect of added nitrogen on the rate of decomposition of organic matter. Biological Review, 63 : $433-462$.

Franzluebbers, A.J. 2002. Soil organic matter stratification ratio as an indicator of soil quality. Soil and Tillage Research, $66: 95$ - 106 .

Franzluebbers, A. J . and Arshad, M. A. 1997. Soil microbial biomass and mineralizable carbon of waterstable aggregates affected by texture and tillage. Soil Science Society of A merica Journal, $61: 1090$ - 1097.

Garcia, C. , Hemandez, T. and Costa , F. 1994. Microbial activity in soil under Mediterranean environmental condr tions. Soil Biology and Biochemistry, 26:1185 - 1191.

Garland, J.L. and Mills, A.L. 1991. Classification and char acterization of heterotrophic microbial communities on the basis of patterns of community-level sole-carbon-source utilization. Applied and Environmental Microbiology, 57 : 2351 - 2359.

Goyal, S. , Mishra, M. M., Hooda, I. S. and Singh, R. 1992. Organic matter-microbial biomass relationships in field experiments under tropical conditions : effects of inorganic fertilization and organic amendments. Soil Biology and Biochemistry, $24: 1081$ - 1084.

Grayston, S. J. , Wang, S. Q. , Campbell, C. D. and Edwards, A. C. 1998. Selective influence of plant species on microbial diversity in the rhizosphere. Soil Biology and Biochemistry, 30 : 369 - 378.

Hassink, J. , Oude Voshaar, J. H. , Nijhuis, E. H. and van Veen, J. A. 1991. Dynamics of the microbial populations of a reclaimed-polder soil under a conventional and a reducedinput farming system. Soil Biology and Biochemistry, $23: 515$ - 524.

Hedges, R. W. and Messens, E. 1990. Genetic appects of rhizosphere interactions. In: Lynch, J. M. (ed. ), The Rhizosphere. Wiley, New York, 129 - 176.

Hill, G. T. , Mitkowski, N. A., Aldrich, W.L., Emele, L. R. , J urkoni, D. D. , Ficke, A. , Maldonado Ramirez, 
S. , Lynch, S. T. and Nelson, E. B. 2000. Methods for assessing the composition and diversity of soil microbial communities. Applied Soil Ecology, 15: 25 - 36.

Hoitink, H. A. J . and Boehm, M. J. 1999. Biocontrol within the context of soil microbial communities: a substrate dependent phenomenon. A nnual Review in Phytopathology, $37: 427$ - 446.

Ibekwe, A. M. and Kennedy, A. C. 1998. Phospholipid fatty acid profiles and carbon utilization patterns for analysis of microbial community structure under field and greenhouse conditions. FEMS Microbial Ecology, 26:151 - 163.

Jena , P. K. , Adha, T. K. and Rao, V. R. 1987. Influence of carbaryl on nitrogenase activity and combinations of bur tachlor and carbofuran on nitrofixing microorganisms in paddy soils. Pestic Science, 19:179 - 184.

Johnsen, K. , Jacobsen, C. S. and Torsvik, V. 2001. Pestir cide effects on bacterial diversity in agricultural soils - a review. Biology and Fertility of Soils, $33: 443$ - 453.

Kanazawa, S. , Asakawa, S. and Takai, Y. 1988. Effect on fertilizer and manure application on microbial numbers, biomass, and enzyme activities in volcanic ash soils. I. Microbial numbers and biomass carbon. Soil Science and Plant Nutrition, $34: 429$ - 439.

Kaye, J. P. and Hart, S. C. 1997. Competition for nitrogen between plants and soil microorganisms. Trends in Ecology and Evolution, $12: 139$ - 142.

Kennedy, A. C. 1999a. Bacterial diversity in agroecosystem. A griculture, Ecosystems and Environment, 74:65 - 76.

Kennedy, A. C. 1999b. The rhizosphere and spermosphere. In: Sylvia , D. M. , Fuhrmann , J. J . , Hartel , P. G. and Zuberer, D. A. (eds.), Principles and Applications of Soil Microbiology. Prentice Hall, Upper Saddle River, NJ , 389 - 407.

Kishinevsky, B. , Lobel , R. and Lifshitz, N. 1988. Effects of some commercial herbicides on rhizobia and their symbiosis with peanuts. Weed Research, 28: 291 - 296.

Liu, X. Y. , Lindemann, W. C. , Whitford, W. G. and Stein er, R. L. , 2000. Microbial diversity and activity of disturbed soil in the northern Chihuahuan desert. Biology and Fertility of Soils, 32 : 243 - 249.

Lovell, R. D. , Jarvis, S. C. and Bardgett, R. D. 1995. Soil microbial biomass and activity in long-term grassland: effects of management change. Soil Biology and Biochemistry, 27 : 969 - 975.

Lupwayi , N. Z. , Arshad, M. A. , Rice, W. A. and Clayton, G. W. 2001a. Bacterial diversity in water-stable aggregates of soils under conventional and zero tillage management. A pplied Soil Ecology, 16: 251 - 261.

Lupwayi , N. Z. , Monreal , M. A. , Clayton, G. W. , Grant,
C. A. , Johnston, A. M. and Rice, W. A. 2001b. Soil microbial biomass and diversity respond to tillage and sulphur fertilizers. Canadian Journal of Soil Science, 81 : $577-589$.

Lupwayi, N. Z. , Rice, W. A. and Clayton, G. W. 1998. Soil microbial diversity and community structure under wheat as influenced by tillage and crop rotation. Soil Biology and Biochemistry, 30:1733 - 1741 .

Lupwayi, N. Z. , Rice, W. A. and Clayton, G. W. 1999. Soil microbial biomass and carbon dioxide flux under wheat as influenced by tillage and crop rotation. Canadian Journal of Soil Science, 79: 273 - 280.

Lynch, J . M. and Panting, L. M. 1982. Effects of season, cultivation and nitrogen fertilizer on the size of the soil microbial biomass. Journal of the Science of Food and A griculture, $33: 249$ - 252

Martinez- Toledo , M. V. , de la Rubia, T. , Moreno , J . , Gon zalez-Lopez, J . 1988. Effect of diflubenzuron on Azotobacter nitrogen fixation in soil. Chemosphere, $17: 829$ - 834.

Martinez Toledo, M. V. , Salmerón, V. and GonzalezLopez, J. 1992a. Effect of an organophosphorus insecticide, profenofo, on agricultural soil microflora. Chemosphere, 24 : $71-80$.

Martinez Toledo, M. V. , Salmeron, V. and GonzalezLopez, J. 1992b. Effect of the insecticides pyrimifosmethyl and chlorpyrlfos on soil microflora in an agricultural loam. Plant and Soil, $147: 25$ - 30.

Miller, H. J. , Henken, G. and van Veen J. A. 1989. Varia tion and composition of bacterial populations in the rhizosphere of maize, wheat and grass cultivars. Canadian Journal of Microbiology, $35: 656$ - 660.

Paul, E. A. and Clark, F. E. 1989. Soil Microbiology and Biochemistry. Academic Press, New York.

Popova, L. V. 1993. Effect of fertility levels on soil microf ungi. Eurasian Soil Science, 25: 96 - 100.

Ramos, M. L. G. and Ribeiro, W. O . J. 1993. Effect of fungicides on survival on Rhizobium on seeds and the nodulation of bean (Phaseolus vulgaris L.). Plant and Soil, $152: 145$ - 150 .

Revellin , C. , de Canson , B. and Catroux , G. 1992. Effect of a mixture of chlorpyrifos and lindane on the symbiosis of Bradyrhizobium japonicum and soybean [ Glycine max (L. ) Merril]. Pestic Science, 36:69 - 74.

Ritchie, N.J. , Schutter, M. E. , Dick, R. P. and Myrold, D. D. 2000. Use of length heterogeneity PCR and fatty acid methyl ester profiles to characterize microbial communities in soil. Applied and Environmental Microbiology, 66 : 1668 - 1675.

Sarathchandra, S. U., Ghani, A. , Yeates, G. W. , Burch, 
G. and Cox , N. R. 2001. Effect of nitrogen and phosphate fertilisers on microbial and nematode diversity in pasture soils. Soil Biology and Biochemistry, 33 : 953 - 964.

Schimel , J . 1995. Ecosystem consequences of microbial diversity and community structure. In: Chapin, F. S. and Korner, C. (eds.), A rctic and Alpine Biodiversity: Patterns, Causes, and Ecosystem Consequences. Springer Verlag, Berlin , 239 - 254.

Schutter, M. E. , Sandeno, J. M. and Dick, R. P. 2001. Seasonal, soil type, and alternative management influences on microbial communities of vegetable cropping systems. Biology and Fertility of Soils, $34: 397$ - 410.

Thirup , L. , Ekelund, F. , Johnsen, K. and Jacobsen, C. S. 2000. Population dynamics of the fast-growing sub-populations of Pseudomonas and total bacteria, and their protozoan grazers, revealed by fenpropimorph treatment. Soil Biology and Biochemistry, 32 : 1615 - 1623.

Thirup , L. , Johnsen, K. , Torsvik, V. , Spliid, N. H. and Jacobsen, C. S. 2001. Effects of fenpropimorph on bacteria and fungi during decomposition of barley roots. Soil Biology and Biochemistry, $33: 1517$ - 1524.

Tiquia, S. M. , Lloyd, J. , Herms, D. A. , Hoitink, H. A. J. and Michel , F. C. Jr. 2002. Effects of mulching and fertilization on soil nutrients, microbial activity and rhizosphere bacterial community structure determined by analysis of TRFLPs of PCR-amplified 16S rRNA genes. A $p^{-}$ plied Soil Ecology, 21: 31 - 48.

Topp, E. , Valleys, T. and Soulas, G. 1997. Pesticides: mi crobial degradation and effects on microorganisms. In : van Elsas, J. D. , Trevors, J. T. and Wellington, E. M. H. (eds.) , Modern Soil Microbiology. Dekker, New York, $547-575$.

Vanotti, M. B., Leclerc, S. A. and Bundy, L. G. 1995. Short term effects of nitrogen fertilization on soil organic nitrogen availability. Soil Science Society of A merica Journal, 59: 1350 - 1359.

Waid, J. S. 1999. Does soil biodiversity depend upon metabiotic activity and influences? Applied Soil Ecology, 13 : $151-158$.

Wardle, D. A. and Parkinson, D. 1992. Influence of the her bicides $2,4-\mathrm{D}$ and glyphosate on soil microbial biomass and activity: a field experiment. Soil Biology and Biochemistry, 24 : 185 - 186.

Wardle, D. A. 1992. A comparative assessment of factors which influence microbial biomass carbon and nitrogen levels in soil. Biological Review, 67 : 321 - 358.

Widden, P. , Howson, G. and French, D. D. 1986. Use of cotton strips to relate fungal community structure to cellulose decomposition rate in the field. Soil Biology and Biochemistry, 18: 335 - 337.

Workneh, F. and van Bruggen, A. H. C. 1994. Microbial density, composition, and diversity in organically and conventionally managed rhizosphere soil in relation to suppression of corky root of tomatoes. Applied Soil Ecology, 1 : $219-230$.

Yan, F. , McBratney, A. B. and Copeland, L. 2000. Functional substrate biodiversity of cultivated and uncultivated A horizons of vertisols in NW New South Wales. Geoder$m a, 96: 321-343$.

Yang, Y. H. , Yao , J. , Hu, S. and Qi, Y. 2000. Effects of agricultural chemicals on DNA sequence diversity of soil microbial community: a study with RAPD marker. $\mathrm{Mi}^{-}$ crobial Ecology, 39: 72 - 79.

Zelles, L. 1999. Fatty acid patterns of phospholipids and lipopolysaccharides in the characterisation of microbial communities in soil : a review. Biology and Fertility of Soils, 29:111 - 129. 